DOI: https://doi.org/10.34069/AI/2021.44.08.24 How to Cite:

Hobela, V., Blikhar, M., Syrovackyi, V., Maraieva, U., \& Dudiuk, V. (2021). Economic and legal measures for ensuring the economy greening in post-pandemic period. Amazonia Investiga, 10(44), 252-260. https://doi.org/10.34069/AI/2021.44.08.24

\title{
Economic and legal measures for ensuring the economy greening in post-pandemic period
}

\section{ЕКОНОМІКО-ПРАВОВІ ЗАХОДИ ЗАБЕЗПЕЧЕННЯ ЕКОЛОГІЗАЦІї ЕКОНОМІКИ У ПОСТ ПАНДЕМІЧНИЙ ПЕРІОД}

Received: July 13, 2021

\section{Abstract}

The purpose of the study was to develop economic and legal measures to create a green economy model by assessing the effectiveness of greening tools. To achieve the goal it was necessary to solve several problems. Firstly, to evaluate the effectiveness of greening tools using expert analysis techniques. Secondly, to develop measures to ensure the economy greening through the use of the most effective greening tools. Theoretical basis. The economy greening is extremely important, especially in the postpandemic period - a period of intensive economic recovery, which might contribute to the strengthening of environmental problems. Accordingly, the study aims to identify the most effective tools for greening to develop measures for the ecologigaly healthy economic recovery in the post-pandemic period. Scientific novelty. The effectiveness of greening tools was evaluated and several economic and legal measures were developed, which will contribute to the economy greening intensification.
Accepted: September 15, 2021

Written by:
Hobela Volodymyr ${ }^{97}$
https://orcid.org/0000-0001-7438-2329
Blikhar Mariia ${ }^{98}$
https://orcid.org/0000-0003-2974-0419
Syrovackyi Valerij ${ }^{99}$
https://orcid.org/0000-0001-8465-9942
Maraieva Uliana ${ }^{100}$
https://orcid.org/0000-0002-2600-8532
Dudiuk Volodymyr $\mathbf{r}^{\mathbf{1 0 1}}$
https://orcid.org/0000-0003-4649-4280

\section{Анотація}

Метою дослідження $\epsilon$ розробка економікоправових заходів для створення моделі зеленої економіки за допомогою оцінки ефективності інструментів екологізації. Для досягнення мети дослідження необхідно вирішити кілька завдань. По-перше, оцінити ефективність інструментів екологізації за допомогою методики експертного аналізу. По-друге, розробити заходи щодо забезпечення екологізації економіки шляхом використання найефективніших інструментів екологізації. Теоретичний базис. Екологізація економіки для формування моделі зеленої економіки є вкрай важливою, особливо у пост пандемічний період - період інтенсивного відновлення економіки, що може сприяти посиленню екологічних проблем. Відповідно, дослідження спрямоване на визначення найефективніших інструментів екологізації для розробки ефективних заходів екологізації економіки у пост пандемічний період. Наукова новизна. У дослідженні здійснено оцінку ефективності інструментів

\footnotetext{
${ }^{97}$ Candidate of Economic Sciences, Associate Professor of the Department of Management, of Institute of Management, Psychology and Security of Lviv State University of Internal Affairs, Ukraine.

98 Doctor of Juridical Sciences, Candidate of Economic Sciences, Docent, Professor at the Department of Administrative and Informational Law, of Institute of Jurisprudence, Psychology and Innovative Education, Lviv National University Lviv Polytechnic, Ukraine.

${ }^{99}$ Doctor of Juridical Sciences, Advocate of Kyiv, Ukraine.

${ }^{100}$ Candidate of Philosophy Sciences, Associate Professor of the Department of Philosophy, of Uzhhorod National University, Ukraine.

${ }^{101}$ Candidate of Economic Sciences, Docent, Associate Professor of the Organization Management and administration Department, Institute of Ecological Economics and Management, National Forestry University of Ukraine, Ukraine.
} 




Conclusions. The study proposed to intensify the economy greening by using the most effective greening tools whose effectiveness was assessed by using expert analysis. The most effective greening tools were identified: environmental taxes, quotas, environmental funds, environmental audit, and environmental certification. Based on the results of the study, several economic and legal measures for economy greening in the post-pandemic period were developed.

Key words: greening, green economy, environmental issues, post-pandemic period, greening tools, Kendall methodology. екологізації та запропоновано економікоправові звходи, що сприятимуть інтенсифікації екологізації. Висновки. У дослідженні запропоновано інтенсифікувати процеси екологізації економіки шляхом використання найбільш ефективних інструментів екологізації, що встановлені в результаті експертного опитування. Здійснено оцінку ефективності інструментів екологізації за допомогою експертного аналізу та встановлено найбільш ефективні інструменти екологізації: екологічні податки, квоти, екологічні фонди, екологічний аудит та екологічна сертифікація. На основі результатів дослідження розроблено низку економіко-правових заходів щодо екологізації економіки у пост пандемічний період.

Ключові слова: екологізація, зелена економіка, екологічні проблеми, постпандемічний період, інструменти екологізації, методика Кендалла.

\section{Introduction}

The modern economy is marked by intensive use of natural resources, significant reduction of them, irrational natural resource management, which, in turn, causes a crisis in the environment and a notable number of environmental disasters. Furthermore, globalization also contributes to global environmental problems. At the same time, a significant part of the world's population is below the poverty line, experiencing shortages in food and drinking water. There is a significant level of population stratification. The evergrowing population and consumerism are the driving forces that stimulate the growth of production and consumption of various goods. However, such activities cause several environmental problems. The current state of the environment requires an immediate reduction in the number of harmful substances that enter ecosystems. As a result, a situation is formed from which it is difficult to find a way out. All this makes the economy greening relevant.

Several researchers have proposed a new model of the economy, the focus of which is on the environment, and the economic system is dependent on it. That is, the economic system is part of the natural environment and objectively exists in it. In this case, the question of preserving the environment and the normal conditions for the functioning of future generations determines the future conditions of existence of the actual economic system as its component. Thus, the marginal deviations of the state of the natural system directly affect the state of the economic system in the short or long term. Excessive use of natural resources will cause systemic changes in the world economy and will have tangible negative consequences for future generations. The spread of such ideas in scientific circles is called the concept of "green economy". It can be argued that there is an urgent need to form a modern concept of social development, which will provide not only economic development but a safe environment. That is, it will be aimed at ensuring a balance between economic and environmental systems. Achieving this effect is possible through the maximum convergence and interpenetration of economic and environmental policies. As a result, the economic system will safely coexist with the ecological system. The most effective way to achieve this state is the greening of all economic processes.

This suggests that, to ensure the greening of the economy and transition to the "green economy" it is necessary to identify the most effective tools for greening the economy and develop ways to implement them in practice.

Also, the purpose of the study is to develop measures for establishing the green economy model based on the results of the greening tools efficiency estimation. To fulfill the purpose of the study several issues have to be solved. Firstly, to estimate the greening tool's efficiency by experts analysis. To do this we require to generate an expert group, find out the level of experts consensus by using the Kendall 
methodology and conduct the expert analysis. Secondly, to develop measures to ensure a green economy through the use of the most effective greening tools.

\section{Methodology}

The paper uses several general scientific research methods to develop economic and legal measures to green the economy in the post-pandemic period. In particular, the method of system analysis and synthesis to confirm the hypothesis of environmental degradation after crises caused by the rapid economic recovery expected after the COVID-19 pandemic. Thus, this area of research is updated. Using the method of analytical forecasting and induction, three probable scenarios of economic recovery and the corresponding state of the environment are identified. Using the method of expert survey, the analysis of the effectiveness of greening tools. Using the method of Kendall, the level of experts agreement was established. Based on the results of an expert survey and using a comparative analytical method, the reason for the inefficiency of environmental taxation was identified - too low tax rates. Based on the results of the survey, several economic and legal measures have been developed to green the economy by using the most effective greening tools.

\section{Theoretical framework or Literature Review}

A characteristic feature of the modern economy is several crises and a significant number of global environmental issues. The need for economy greening and the transition to the green economy has become an urgent area of research. Representatives of the scientific community studied the problems of forming a model of the green economy (Pearce, 1990; Affolderbach, 2020) and building an environmentally healthy model of world economic development (Daly, \& Farley, 2004) studied the problems of the ecological economy and ways of economic transformation. There are some researches (Chmyr \& Zakharkevych, 2013), and (Drebot, 2001) devoted to the green economy and ecologically safe sustainable development. A relevant area of research for several scientists was considering ways to implement the principles of green economy as a tool for sustainable learning (Schulz \& Affolderbach, 2015), and the role of sustainable learning in ensuring the economy greening (Tarnawska, 2013; Kumar, 2017; Gormally, 2019) and studied innovations and environmental innovations as tools for shaping the green economy. Also, the ways and means of greening cities and agglomerations were studied (Juhola, 2018). The studies are devoted to the general problems of sustainable development and the formation of a green economy (Dymitrow \& Halfacree, 2018). The scholars examined the nexus between globalization, energy consumption, and economic growth to promote the green economy and environment. Their study has identified the link between GDP growth and carbon emission and found bidirectional causality between economic growth and energy use (Ascensao et al., 2018). Other scholars analyzed greening lending as a tool for green economy and sustainable development promotion (Yuan \& Gallagher, 2018). Moreover, the analysis of innovation stages, knowledge spillover, and green economy development was conducted. This study proposed a model to investigate the effects between the different innovation stages and the green economy (Zhao, Jiang, \& Wang, (2019)). The scholars analyzed the impact of financial development and globalization on the environment and determined the indicators for assessing this impact (Saud, Chen, Haseeb, \& Sumayya 2020). The research of globalization affects the green economy and environment and was conducted. It determined the nexus between energy consumption, carbon dioxide emissions, and economic growth (Khalid et al., 2021). Furthermore, the impact of foreign direct investment on $\mathrm{CO} 2$ emissions in emerging countries was examined (Xie, Wang \& Cong, 2020). The scientists also studied the implications of financial regulations on a sustainable green economy. They concluded that financial regulations are significant for achieving a sustainable green economy (Odugbesan et al., (2021). The pros and cons, and main bottlenecks of green growth were determined by using a multidimensional approach (Demiral \& Demiral, 2021). The scholars used the difference in differences (DID) method to evaluate the mean causal effects of a treatment on an outcome of the determinants of scaling up green financing and climate change mitigation in different countries (Nawaz et al, 2021).

However, despite the significant number of scientific papers remained insufficiently studied. Accordingly, this study was aimed at determining the effectiveness of economy greening tools, and based on this proposals for intensifying economy greening to transit to a green economy were developed.

The object is to develop measures for establishing the green economy model based on the results of the greening tools efficiency estimation. 


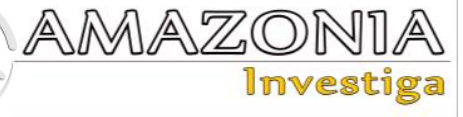

Results and discussions

Despite the predicted severe consequences of the COVID-19 pandemic for the world economy, we should remark that quarantine restrictions have to lead to improved environmental health. However, the improvement of environmental health is occurring while the crisis in the world economy and the general recession. Accordingly, the downward trend in pollution will not last long, as the gradual end of quarantine restrictions will lead to increased economic activity and lead to the opposite consequences - increased emissions and environmental pollution due to increased industrial production.

It is necessary to decide which way to restore the economy to preserve the environment. It is essential to take into account the previous experience of post-crisis economic recovery in 2008-2009 when the level of pollution exceeded the pre-crisis level. The reason for this was a significant increase in carbon consumption for economic recovery and, as a result, a significant increase in environmental pollution and greenhouse gas emissions. Accordingly, to determine the ways of economic recovery, this experience should be taken into account and efforts should be directed to economic recovery and economy greening. In other words to reorient production and consumption to low-carbon technologies, intensify the use of renewable resources and energy, introduce the ideas of recycling and a Circular economy, promote the development of Bionics, Industrial Ecology, and environmental design.

The predicted consequences of the COVID-19 pandemic for the economic system and environment are as follows (Hobela, 2021 a):

1. Economic and environmental crisis. Economic recovery may exacerbate the crisis. We can also assume that after the end of the pandemic, people will realize that solving climate problems and global environmental problems are too "expensive" pleasure, as it requires sacrificing a habitual and comfortable lifestyle. The consequence of this may be a total disregard for the ideas of the ecological economy and the final industrialization, which will accelerate the ecological catastrophe on a global scale.

2. Economic recovery and environmental crisis. Active stimulation of industrial recovery will lead to an increase in anthropogenic impact on nature. In this course of events, the onset of new cataclysms is only a matter of time.

3. Economic recovery and improvement of environmental health. To accomplish this it is vital to invest in the economy on the principles of environmentally healthy development and economy greening.

We should work on creating a strategy for economic recovery in an environmentally healthy way. This is the way of economy greening and transition to a green economy. That is why there is a need to study the effectiveness of greening tools, which should be used to achieve a positive economic and environmental effect. In the process of research, the effectiveness of the greening tools was evaluated.

To implement this approach, the following algorithm was used:

1. Formation of the expert group. Leading specialists in the field of ecological economics, natural resources management, public authorities, and practical specialists were selected to the group.

2. Determining the degree of agreement of experts' opinions by calculating the concordance coefficient and assessing the validity of the survey results.

3. Drawing up control questions and formation of expert letters of estimation.

4. Conducting an expert survey and processing the survey results.

5. Development of relevant conclusions and generalization of results.

To determine the compatibility of the members of the expert group opinion Kendall's method was used, which provides for the calculation of the overall rank correlation coefficient - the concordance coefficient. This methodology involves determining the degree of consistency of expert opinion in all areas, factors, and parameters, as well as the formation of conclusions about the level of consistency of expert opinions. Bringing this rate up to 1.0 means a greater degree of agreement between experts, and vice versa. The limit value of the concordance coefficient is 0.5 . That is, the value of the indicator is more than 0.5 - opinions are agreed, less than 0.5 - opinions are not agreed. The concordance coefficient is calculated by the formula:

$$
\mathrm{W}=\frac{12 \times \sum \mathrm{d} 2}{\mathrm{~m}^{2}\left(\mathrm{n}^{3}-\mathrm{n}\right)},
$$

were:

$\mathrm{W}$ - concordance coefficient; 
$\mathrm{S}$ - the sum of the squares of the deviations;

$\mathrm{m}$ - number of experts;

$\mathrm{n}-$ number of parameters.

$$
d^{2}=\sum_{4}^{1}\left(S-S_{A V E R}\right)^{2},
$$

were:

$\mathrm{d}^{2}$ - square deviation;

$\mathrm{S}$ - the total rank of the object;

$\mathrm{S}_{\text {aver }}$ - the average rank of the parameter;
Generally, to calculate the coefficient the following indicators were calculated:

$\mathrm{S}$ - the total rank of the parameter;

$\mathrm{d}$ - deviation the sum of ranks from the average sum of ranks;

$\mathrm{d}^{2}-$ square deviation;

$\sum \mathrm{d}^{2}-$ the sum of the squares deviations.

Table 1.

Estimated data for the Concordance coefficient.

\begin{tabular}{|c|c|c|c|c|c|c|c|c|c|c|c|c|c|}
\hline Expert & 1 & 2 & 3 & 4 & 5 & 6 & 7 & 8 & 9 & 10 & $\mathrm{~S}$ & $d$ & $d^{2}$ \\
\hline Parameter 1 & 4 & 3 & 4 & 4 & 4 & 3 & 4 & 3 & 4 & 3 & 36 & -11 & 121 \\
\hline Parameter 2 & 2 & 4 & 2 & 3 & 3 & 4 & 3 & 4 & 3 & 2 & 30 & -5 & 25 \\
\hline Parameter 3 & 1 & 2 & 3 & 1 & 2 & 2 & 1 & 2 & 1 & 4 & 19 & 6 & 36 \\
\hline Parameter 4 & 3 & 1 & 1 & 2 & 1 & 1 & 2 & 1 & 2 & 1 & 15 & 10 & 100 \\
\hline$\sum \mathbf{d}^{2}$ & & & & & & & & & & & & & 282 \\
\hline
\end{tabular}

Source: Own authorship.

Substituting the obtained results into the formula, the concordance coefficient was calculated, it gives 0.564 . The obtained value exceeds the limit value of the concordance coefficient and certifies the validity of expert opinions. Thus, the effectiveness of greening tools was established. The results of the calculations are presented in Table 2.

Table 2.

The results of expert's analysis.

\begin{tabular}{lll}
\hline o & Greening tools & Rating \\
\hline 1 & Environmental taxes & 50 \\
2 & Quotas & 46 \\
3 & Environmental funds & 46 \\
4 & Environmental audit & 43 \\
5 & Ecological certification & 42 \\
6 & Fines for excessive use of resources & 40 \\
7 & Mandatory environmental information disclosure & 39 \\
8 & Environmental monitoring & 36 \\
9 & Accelerated amortization of environmental protection's funds & 33 \\
10 & Environmental insurance & 32 \\
11 & Licensing & 32 \\
12 & Green Bonds & 30 \\
13 & Ecological analysis of the product life cycle & 30 \\
14 & Subsidies & 30 \\
15 & State support of ecological production & 29 \\
16 & Eco-pledge & 29 \\
17 & Custom duty & 27 \\
18 & Grants & 26 \\
19 & Environmental indicators & 26 \\
20 & Soft loans & 25 \\
\hline
\end{tabular}

Source: Own authorship.

The most effective greening tools contain environmental taxes, quotas, environmental funds, environmental audits, ecological certification. 


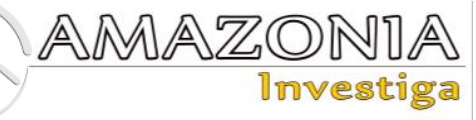

Based on the study of the effectiveness of greening tools, we propose to develop measures to intensify greening and transition to a green economy.

Among the principal offers we propose to consider the following:

- increase of ecological taxes;

- creation of the Environmental Protection Fund;

- introduction and use of Green Bonds;

- improvement of the citizen's ecological rights realization mechanism.

Firstly, the study found that environmental taxes will have a profound effect on the environment. In addition, to transform the negative external effects into internal ones, several environmental taxes have been introduced within the framework of the Pareto compensation principle, in particular on $\mathrm{CO} 2$ emissions. However, these types of taxes are not as effective. We believe that the reason for this is too low a tax rate $(\$ 0.36$ per 1 ton of $\mathrm{CO} 2)$ compared to other industrialized countries (from $\$ 20$ to $\$ 150$ per 1 ton of CO2) (Hobela, 2021 a).

A study of the share of environmental taxes in the structure of tax payments of Ukraine and other developed countries, confirms our statement that environmental tax rates are unreasonable. Accordingly, there is a need to set the environmental tax at a level that will compensate for environmental damage and encourage a reduction in the energy intensity of production. This approach will allow balancing environmental and economic interests during the formation of the environmental tax. In particular, the increase in the size of the environmental tax in Ukraine from $\$ 0.02$ to $\$ 0.36$ caused a decrease in $\mathrm{CO} 2$ volumes and total pollution. Thus, environmental taxes are the most effective tool for greening, and their impact on the environment remains quite significant. The analysis data show that since 2017 there has been a reduction in $\mathrm{CO} 2$ emissions and total pollution, which is certainly the reason for the increase in environmental taxes in Ukraine (Hobela, 2021 a).

Also, comparing the amount of pollution and the amount of carbon dioxide emissions, we can declare that they are reduced and increased in the number of tax revenues from environmental taxes. Note that the increase in the tax rate has led to a decrease in pollution, which is certainly a very positive aspect.

Secondly, having analyzed the current legislation and revenues to the state budget (Hobela, 2021 b), we conclude that for the most part environmental taxes do not come to this fund in full. There are also many examples of irrationality and misuse of the fund. We consider the creation of the Environmental Protection Fund as a separate legal entity that will accumulate all environmental payments to be the best solution to this problem. As mentioned above, an important aspect of ensuring greening is the obligation to inform the population about the state of the environment and the main measures taken to improve the environmental situation. This approach will contribute to the formation of the environmental behavior of consumers. With this in mind, it is recommended to create an online platform to inform the public about the use of the Environmental Protection Fund to monitor the implementation of greening measures and their financing.

Thirdly, the economy greening and the transition to renewable energy use is a widely recognized strategic direction for the development of the world community and Ukraine. However, this process is not as active as we would like. The main reason for this is the lack of funds, because greening measures, for the most part, require significant investment.

Let's analyze the share of renewable energy in Ukraine and other countries in 2014-2019 Fig. 1. As we see, Ukraine's indicators are extremely low. That is why the use of one of the most effective tools of greening - green bonds has become relevant. 




Figure 1. The share of renewable energy of studied countries in 2014-2019.

Source: Own authorship.

Fourthly, an important area of intensification of greening is the improvement of some norms of domestic environmental law. At the same time, it can be concluded that the world community is deeply concerned about environmental health, which is manifested in the relevant processes of the greening of international law, EU law, and national law. In general, the priority of development is the ecological balance of forms, methods, and ways of interaction between society and nature. So, let's pay attention to certain shortcomings of domestic environmental law. Many norms are generalized and not specified (Shevchuk, Blikhar, Zabzaliuk, \& Tataryn, 2020). First of all, it is necessary to improve the regulatory and legal support for greening and the formation of economic tools, which provides for improvements to the legislation.

- identify promising activities that require state support in the form of soft loans and provide a mechanism for the legal regulation of such activities;

- expand and detail the list of measures and activities for which it is advisable to apply economic incentives, in particular, to determine preferential tax rates, rates of accelerated depreciation of environmental funds, etc.

An important aspect of improving environmental legislation is to improve the system of implementation of legal norms relating to the protection of environmental rights of citizens. It is about removing barriers for citizens to protect their environmental rights in the judiciary and law enforcement agencies, to obtain timely access to information on the state and extent of environmental pollution, and so on. To do this, we recommend:

- expand the powers of the environmental auditor and the level of his responsibility for conducting a biased environmental impact assessment;

- establish responsibility for violating the planned indicators of environmental impact assessment depending on the level of their deviation from the actual values.

\section{Scientific novelty}

The study substantiates the need to intensify the economy greening to form a model of a green economy in the post-pandemic period. The effectiveness of greening tools has been evaluated and several economic and legal measures have been developed, which will contribute to the intensification of greening through the use of the most effective greening tools in the post-pandemic period.

\section{Conclusions}

The study backs up the importance of the economy greening to transit for a green economy model in the post-pandemic period. The effective use of greening tools is supposed to be the best prospect for the economy greening ensuring. The method of greening tools effectiveness assessment was proposed to determine the most effective of them. To do this an algorithm was formed, which consists of the following stages: 




formation of the expert group; determining the degree of agreement of experts' opinions by calculating the concordance coefficient and assessing the validity of the survey results; drawing up control questions and forming expert evaluation sheets; conducting an expert survey and processing the survey results; development of appropriate conclusions and summarizing the results.

Due to this method, the most effective tools for Ukraine's economy greening in the postpandemic period were identified: environmental taxes, quotas, environmental funds, environmental audit, and ecological certification. Based on the results of the study, the main economic and legal measures for establishing the green economy model were proposed.

\section{Bibliographic references}

Affolderbach, J. (2020). Translating green economy concepts into practice: ideas pitches as learning tools for sustainability education. Journal of Geography in Higher Education. doi.org/10.1080/03098265.2020.1849063

Anser, K.M., Usman, M., Godil, D. I., Shabbir, M. S., Sharif, A., Tabash, M. I. \& Bares Lopez, L. (2021) Correction to: Does globalization affect the green economy and environment? The relationship between energy consumption, carbon dioxide emissions, and economic growth. Environ Sci Pollut Res. doi.org/10.1007/s11356-021-14243-4.

Ascensao, F., Fahrig, L., Clevenger, A., et al. (2018). Environmental challenges for the Belt and Road Initiative. Nature Sustainability, 206-209. doi.org/10.1038/s41893-018-0059-3.

Chmyr, O., \& Zakharkevych, N. (2013). "Green" economy: essence, goals and basic principles. Economic Bulletin of Donbass, 33, 54-62. Recovered from http://dspace.nbuv.gov.ua/handle/123456789 /123331? show=full

Daly, H. \& Farley, J. (2004). Ecological Economics. Principles and applications. Washington: Island Press.

Demiral, M., \& Demiral, O. (2021). Where is the gray side of green growth? Theoretical insights, policy directions, and evidence from a multidimensional approach. Environ Sci Pollut Res. doi.org/10.1007/s11356-02113127-x

Drebot, O. (2001). Sustainable development or ecological and economic security?. Collection of scientific articles, 2, 677-680. Recovered from http://eco.com.ua/sites/eco.com.ua/files /lib1/konf/3vze/zb_m/t2/tom_2_s07_p_677_ 680.pdf

Dymitrow, M., \& Halfacree, K. (2018). Sustainability-differently. Bulletin of Geography. Socioeconomic Series, 40(40), 7-16. doi.org/10.2478/bog-2018-0011

Gormally, A. (2019). The role of sustainability in $\mathrm{HE}$ and the GEES disciplines; recommendations for future practice. Journal of Geography in Higher Education, 43(4), 599-608. doi.org/10.1080/03098265.2019.1660627

Hobela, V. (2021 a). Economic and security greening: theory and practice. Lviv: LvDUVS. Recovered from http://dspace.lvduvs.edu.ua/handle/1234567 $890 / 3757$

Hobela, V. (2021 b). Improving the system of legal support for greening as a security activity. Socio-legal studies, 1(11), 140-145. Recovered from http://dspace.lvduvs.edu.ua/handle/1234567 $890 / 3710$

Juhola, S. (2018). Planning for a green city: the Green Factor tool. Urban Forestry and Urban Greening, 34, 254-258. doi.org/10.1016/j.ufug.2018.07.019

Kumar, P. (2017). Innovative tools and new metrics for inclusive green economy. Current opinion in environmental sustainability, 24, 47-51. doi.org/10.1016/j.cosust.2017.01.012

Nawaz, M.A., Seshadri, U., Kumar, P. et al. (2021). Nexus between green finance and climate change mitigation in $\mathrm{N}-11$ and BRICS countries: empirical estimation through difference in differences (DID) approach. Environ Sci Pollut Res, 28, 6504-6519. doi.org/10.1007/s11356-020-10920-y.

Odugbesan, J.A., Rjoub, H., Ifediora, C.U. et al. (2021). Do financial regulations matters for sustainable green economy: evidence from Turkey. Environmental Science and Pollution Research. doi.org/10.1007/s11356021-14645-4.

Pearce, D. (1990). Blueprint 2: Greening the world economy. London: Earthscan Publications ltd.

Saud, S., Chen, S., Haseeb, A., \& Sumayya (2020). The role of financial development and globalization in the environment: Accounting ecological footprint indicators for selected one-belt-one-road initiative countries. Journal of Cleaner Production. doi.org/10.1016/j.jclepro.2019.119518.

Schulz, C., \& Affolderbach, J. (2015). Green growth and alternative forms of economy. Geographical survey, 5, 4-9. Recovered from 
https://www.westermann.de/anlage/4567354 /GruenesWachstum-und-alternativeWirtschaftsformen

Shevchuk, V., Blikhar, V., Zabzaliuk, D., \& Tataryn, N. (2020). The rule of law and inflation in the middle-income countries. Financial and credit activities: problems of theory and practice, 2 (33), 386-399. doi.org/10.18371/fcaptp.v3i38.237453

Tarnawska, K. (2013). Eco-innovations - tools for the transition to green economy. Economics and Management, 18, 735-743. doi.org/10.5755/j01.em.18.4.4485.

Xie Q, Wang, X., \& Cong, X. (2020). How does foreign direct investment affect $\mathrm{CO} 2$ emissions in emerging countries? New findings from a nonlinear panel analysis. Clean Prod. Elsevier Ltd, 119422. doi.org/10.1016/j.jclepro.2019.1194 22

Yuan, F. \& Gallagher, K.P. (2018). Greening development lending in the Americas: trends and determinants. Ecological Economics. Elsevier, 154,

$189-$ 200. doi.org/10.1016/j.ecolecon.2018.07.009

Zhao, S., Jiang, Y., \& Wang, S. (2019). Innovation stages, knowledge spillover, and green economy development: moderating role of absorptive capacity and environmental regulation. Environ Sci Pollut Res, 26, 25312-25325. doi.org/10.1007/s11356-019-05777-9. 